\title{
Improving biohydrogen production using Clostridium beijerinckii immobilized with magnetite nanoparticles
}

\author{
Trevor Seelert • Dipankar Ghosh • Viviane Yargeau
}

Received: 14 September 2014 / Revised: 12 February 2015 / Accepted: 14 February 2015 /Published online: 3 March 2015

(C) Springer-Verlag Berlin Heidelberg 2015

\begin{abstract}
In order to supplement the need for alternative energy resources within the near future, enhancing the production of biohydrogen with immobilized Clostridium beijerinckii NCIMB8052 was investigated. Magnetite nanoparticles were functionalized, with chitosan and alginic acid polyelectrolytes using a layer-by-layer method, to promote bacterial attachment. Cultivating C. beijerinckii with these nanoparticles resulted in a shorter lag growth phase and increased total biohydrogen production within 100-ml, 250-ml and 3.6-L reactors compared with freely suspended organisms. The greatest hydrogen yield was obtained in the 250 $\mathrm{ml}$ reactor with a value of $2.1 \pm 0.7 \mathrm{~mol} \mathrm{H}_{2} / \mathrm{mol}$ glucose, corresponding to substrate conversion and energy conversion efficiencies of $52 \pm 18$ and $10 \pm 3 \%$, respectively. The hydrogen yields obtained using the immobilized bacteria are comparable to values found in literature. However, to make this process viable, further improvements are required to increase the substrate and energy conversion efficiencies.
\end{abstract}

Keywords Biohydrogen · Clostridium beijerinckii . Magnetite $\cdot$ Chitosan $\cdot$ Alginic acid $\cdot$ Immobilization

Trevor Seelert and Dipankar Ghosh contributed equally to this work.

Electronic supplementary material The online version of this article (doi:10.1007/s00253-015-6484-6) contains supplementary material, which is available to authorized users.

T. Seelert $\cdot$ V. Yargeau $(\bowtie)$

Department of Chemical Engineering, McGill University, 3610

University St., Montréal, QC H3A 2B2, Canada

e-mail: viviane.yargeau@mcgill.ca

D. Ghosh

Département de Microbiologie et Immunologie, Université de Montréal, C.P. 6128, Succ. Centre-ville, Montréal, QC H3C 3J7, Canada

\section{Introduction}

The global population's energy and carbon usage has increased significantly in recent years (Pielke et al. 2008), while current projections indicate energy consumption will increase another $35 \%$ by 2035 compared to 2008 . Of this future energy demand, countries outside the Organization for Economic Cooperation and Development (OECD) are expected to contribute an $85 \%$ increase in their energy usage. The majority of this energy is derived from oil and coal resources (Conti and Holtberg 2011) and thus their use increases the atmospheric $\mathrm{CO}_{2}$ concentrations, contributing to global climate change (Kothari et al. 2010). As a result, alternative energy resources with minimal atmospheric carbon contributions should be investigated to help offset future global energy needs. Finding such alternative resources would accomplish two significant objectives. First, atmospheric carbon emissions would be reduced, decreasing the overall impact on global climate change. Secondly, an alternative energy resource would help lower the differences in environmental footprints between nations having different levels of access to conventional sources of energy. Reaching these objectives would create a more sustainable global energy market (Cranston and Hammond 2010). Renewable energy resources typically produce lower carbon emissions and thus have a reduced environmental impact (Conti and Holtberg 2011; Cullen and Allwood 2010). Hydrogen is considered a strong alternative fuel source as it has the largest energy density per unit mass of all known fuels $(142 \mathrm{~kJ} / \mathrm{g})$ (Ghosh and Hallenbeck 2014) and is considered a "clean fuel" as water is its primary byproduct (Brentner et al. 2010). At present, $95 \%$ of hydrogen is produced through fossil fuel-dependent processes, primarily steam methane reforming of natural gas (Brentner et al. 2010). Other such processes include thermal cracking of natural gas, partial oxidation of hydrocarbons, and coal gasification (Hallenbeck and Ghosh 2009). Most other hydrogen is produced as a by- 
product of chemical processes with water electrolysis contributing a small amount (Brentner et al. 2010). However, not only do the majority of the above processes rely on nonrenewable fossil fuel resources, but they also occur at high temperatures or pressures and are thus energy intensive (Hallenbeck and Ghosh 2009). Hydrogen production through biological processes (biohydrogen) is an alternative production scheme based solely on various renewable resources. Biohydrogen production that does not rely on fossil fuels is typically performed at moderate temperatures and is considered carbon neutral; therefore, it has a no net increase in carbon emissions. As a result, if biohydrogen can be produced in an economically feasible manner, it can be an important alternative to current fuel sources.

Biohydrogen is typically produced through one of four processes: biophotolysis of water, indirect biophotolysis, photofermentation, and dark fermentation. There are pros and cons to each method; however, biophotolysis and indirect biophotolysis have low photochemical efficiencies (Brentner et al. 2010; Hallenbeck and Ghosh 2009), while photofermentation systems do not currently produce hydrogen at a competitive rate (Brentner et al. 2010). Dark fermentation is performed by anaerobic organisms (strict and facultative) such as Clostridium beijerinckii. This process is often accompanied by low substrate conversion efficiency due to competing metabolic pathways as outlined in Fig. S1. However, dark fermentation produces the highest volumetric amount of hydrogen and offers numerous areas for improvement including immobilizing microorganisms, optimizing process conditions, and genetically modifying organisms.

Immobilizing microorganisms on solid substrates retains biomass within the reactor, which has been shown to increase volumetric hydrogen production (Bartacek et al. 2007). For example, Pseudomonas delafieldii, used in an immobilized process to desulfurize a model oil (Li et al. 2009), showed that immobilized and free cultures had similar desulfurizing activity during the first batch cycle. However, immobilized cells could be reused for up to seven batch cycles while retaining $80 \%$ of their specific desulfurizing activity compared to a $15 \%$ retained activity for the suspended cells ( $\mathrm{Li}$ et al. 2009). Further, the production of biohydrogen from different carbon sources has been studied extensively in Clostridium sp. (Ghosh and Hallenbeck 2014), but limited immobilization studies with the objective of producing hydrogen have been carried out with this strain. Some work has been done using immobilizing materials such as polyethylene glycol (Singh et al. 2013), calcium alginate beads (Zhao et al. 2012), polyurethane-activated carbon matrix (Mitchell et al. 2009), ethylene-vinyl acetate copolymer (Lin et al. 2009), polyurethane foam (Jo et al. 2008), silicone gel (Lin et al. 2006), and acetyl cellulose filter (Karube et al. 1982). Although in these works hydrogen yield and productivity were improved using immobilized bacteria compared to suspended cells, major issues still remain about the reusability, stability, and regeneration of these immobilizing materials.

In this study, a novel immobilization technique was investigated, utilizing super paramagnetic nanoparticles (NPs) as the solid substrate for attachment. Using a substrate of this nature would allow organisms to be retained in the bioreactor from batch to batch by applying a magnetic field. This magnetic field separates biomass from the liquid media, allowing fresh liquid to be added to begin new growth and biohydrogen production phases. Therefore, it was hypothesized that successful immobilization of the anaerobic dark fermentation organism $C$. beijerinckii would reduce the lag growth phase between dark fermentation batches; resulting in higher volume of hydrogen produced over a given time period compared to a freely suspended culture. Therefore, overall volumetric hydrogen production would increase compared to a nonimmobilized system over repeated batch cycles, defined as the time from fresh media addition to spent liquid removal. Such a process based on magnetic separation of immobilized bacteria has not yet been designed for hydrogen production, and thus this novel research may help to reduce one of the economical barriers to scale up of an industrial biohydrogen production process.

\section{Materials and methods}

Chitosan (low molecular weight, 75-85\% deacetylated), $\mathrm{NaCl}$, and magnetite nanoparticles (nano powder, $<50 \mathrm{~nm}$ ) were purchased from Sigma-Aldrich (Oakville, ON, Canada). Glacial acetic acid and $\mathrm{NaOH}$ were purchased from Fisher Scientific (Ottawa, ON, Canada). Alginic acid (low viscosity) was purchased from MP Biomedicals (Solon, OH, USA).

Bare magnetite NPs were functionalized prior to immobilization using a layer-by-layer ( $\mathrm{LbL}$ ) technique in order to enhance growth of the bacteria on the surface of the particles. The outermost layer must possess traits to promote bacterial attachment such as biocompatibility, electrostatic, or hydrophobic characteristics or induce nano-size effects when interacting with the bacterial cell wall ( $\mathrm{Li}$ et al. 2009).

This LbL method relies on electrostatic interactions between the core nanoparticles and each subsequent polyelectrolyte layer of opposite charge. Thus, negatively charged core nanoparticles are first coated with a cationic polyelectrolyte, inverting the overall surface charge. An anionic polyelectrolyte can then be deposited as a second layer, again inverting the overall surface charge. This process is repeated for any number of layers whereby the final surface characteristics of the NP-polyelectrolyte hybrid are determined by the final layer (Decher 1997; Masereel et al. 2011). Appropriate polyelectrolytes must be chosen when working with biological 
samples. Primarily, the layer materials must be biocompatible and non-toxic; two common characteristics of many biopolymers. Thus, the procedure used here consisted in depositing chitosan (cationic polyelectrolyte) onto the magnetite NP surface followed by alginic acid (anionic polyelectrolyte) as depicted in Fig. S2. Chitosan is a polyaminosaccharide composed of repeating glucosamine units. Thus, it contains amino groups providing a cationic charge (Pillai et al. 2009). Conversely, alginic acid is composed of $\alpha$-L-guluronate and $\beta$-D-mannuronate units with carboxyl functional groups providing a net anionic charge (Ye et al. 2005). This alginic acid layer is expected to provide the desired conditions discussed above for bacterial attachment to the particle surface. A $2-\mathrm{g} / \mathrm{L}$ chitosan solution was prepared in $2 \%$ acetic acid containing $0.01 \mathrm{M} \mathrm{NaCl}$ (prepared in reverse osmosis (RO) water). This solution was filtered using P8 filter paper and degassed for $20 \mathrm{~min}$ in a Branson 2510 sonicating bath. Dry magnetite NPs were added to the chitosan solution under sonicating to a final concentration of $0.1 \mathrm{~g} / \mathrm{L}$ magnetite. This solution was sonicated for $1 \mathrm{~h}$, shaking by hand every $15 \mathrm{~min}$. NPs were washed twice with $\mathrm{RO}$ water (pH 3 adjusted using acetic acid) by centrifugation at $10,000 \mathrm{rpm}$ for $20 \mathrm{~min}$ followed by resuspension in $\mathrm{RO}$ water $(\mathrm{pH} 3)$. After two wash cycles, the particles were again centrifuged at $10,000 \mathrm{rpm}$ for $20 \mathrm{~min}$ before being re-suspended in $\mathrm{RO}$ water ( $\mathrm{pH} 3$ ). Chitosancoated NPs (C-NPs) were then coated with alginic acid (A$\mathrm{C}-\mathrm{NPs}$ ) according to the same procedure, except all aqueous solutions were set to $\mathrm{pH} 7$ with $\mathrm{NaOH}$.

\section{Confirming coatings and preparing for immobilization}

The presence of chitosan and alginic acid coatings were confirmed through zeta potential measurements and TEM images. The zeta potential of bare magnetite nanoparticles, C-NPs and A-C-NPs were determined using a Malvern Zetasizer Nano ZS90. TEM images were obtained using a Philips CM200 $200 \mathrm{kV}$ TEM. Even though C-NPs would in theory have a greater electrostatic interaction with a negatively charged bacterial cell well, C-NPs poor solubility in neutral solutions resulted in agglomeration, reducing the overall surface area available for immobilization. Therefore, only A-C-NPs were used for immobilization studies. Prior to use in the biohydrogen production experiments, A-C-NPs were transferred to $100 \mathrm{ml}$ serum bottles sparged with argon gas to remove all dissolved oxygen, sealed with butyl rubber stoppers and capped with aluminum crimps before being autoclaved at $121^{\circ} \mathrm{C}$ for $30 \mathrm{~min}$ and cooled down for later use in test bottles.

Immobilizing C. beijerinckii (NCIMB8052) and hydrogen production experiments at the $100-\mathrm{ml}$ scale

C. beijerinckii (NCIMB 8052) were inoculated into 100-ml culture bottles containing $50 \mathrm{ml}$ of oxygen free 2 XTY media
( $5 \mathrm{~g} / \mathrm{L}$ glucose as a carbon source) and grown to mid-log phase at $35^{\circ} \mathrm{C}$ and $100 \mathrm{rpm} .2 \mathrm{xTY}$ media was chosen because of its main constituents: tryptone providing nitrogen sources and amino acids required for bacterial growth and yeast extract acting as an adequate vitamin source. Glucose was added to the media considering that our preliminary work with C. beijerinckii in 2xTY media without glucose (results not shown) resulted in very poor growth (O.D around $0.2-0.3$ after $18 \mathrm{~h}$ ). Autoclaved A-C-NPs prepared previously were then added to the growing $100-\mathrm{ml}$ culture bottle to a final concentration of $0.25 \mathrm{~g} / \mathrm{L}$ and incubated for $6 \mathrm{~h}$. This initial incubation, known as the pre-culture preparation, was meant to allow exponentially growing bacteria to interact with the A-C-NPs and complete the immobilization process. After this time period, a permanent magnet was applied to the culture bottle to separate the nanoparticles and immobilized biomass from the liquid media. The liquid phase was removed and $4 \mathrm{ml}$ of anaerobic phosphate buffered saline (PBS) buffer were added as a washing step. A permanent magnet was again applied to the culture bottle, separating the nanoparticles and immobilized biomass from the PBS buffer. The buffer was then removed and $30 \mathrm{ml}$ of fresh $2 x T Y$ media with $5 \mathrm{~g} / \mathrm{L}$ glucose was added in order to start the biohydrogen production experiment. All the transfers mentioned above were performed using the Hungate technique in order to maintain anaerobic conditions in the test bottles.

Total gas production was measured every $2 \mathrm{~h}$ over the sampling period of up to $24 \mathrm{~h}$ and analyzed for hydrogen concentration. Suspended biomass growth was measured at specific time intervals via optical density measurements. After approximately $24 \mathrm{~h}$ of growth, a permanent magnet was again applied to the culture bottle, separating the immobilized biomass from the liquid media and nonimmobilized bacteria. This spent liquid and nonimmobilized bacteria was then removed and $30 \mathrm{ml}$ of fresh 2 xTY media with $5 \mathrm{~g} / \mathrm{L}$ glucose was added to begin the second fermentation cycle. After approximately $17 \mathrm{~h}$ of growth, this cycling process was repeated for a third fermentation cycle of approximately $12.5 \mathrm{~h}$ in length. Cycling time periods were ended when the stationary growth phase was reached. All trials were performed in duplicate. Controls consisted of test bottles without nanoparticles.

\section{Scale-up of biohydrogen production}

In order to further evaluate the effects of immobilizing C. beijerinckii on the prepared NPs, scale-up trials involving $100-\mathrm{ml}, 250-\mathrm{ml}$, and 3.6-L batch reactors were performed. The fermentation conditions and cycling procedures were identical to the previously described method for the immobilization trials with slight differences: $100-\mathrm{ml}$ trials were performed without the PBS washing step; the 250-ml reactors consisted of $250-\mathrm{ml}$ Wheaton bottles with screw caps 
containing gray butyl rubber septa and the 3.6-L batch trials were performed in a 3.6-L Infors HT Labfors 4 bioreactor with X-DDC operating panel. The 3.6-L reactor was also supplied with $10 \%(w / v) \mathrm{NaOH}$ to maintain reactor $\mathrm{pH}$ at 7.0 and a $1 \%$ $(v / v)$ solution of Antifoam A to prevent foaming. A watercirculating jacket was also used to maintain temperature at $35^{\circ} \mathrm{C}$ within the reactor and agitation was applied via a dual impeller at $500 \mathrm{rpm}$. The 3.6-L reactor trials represent preliminary scale-up as only one trial was performed.

The A-C-NP concentration was also increased in an effort to achieve a greater amount of immobilized biomass and in accordance with NP concentrations used in literature (Ghosh and Pramanik 2010; Ghosh et al. 2010, 2011). Cycling time periods were decreased to a maximum of $13 \mathrm{~h}$ to prevent stationary phase cell death from influencing the activity of immobilized bacteria. The only exception to this rule came if biomass growth in all samples had not reached late exponential phase by $13 \mathrm{~h}$. Finally, a greater volume of fresh media was used to initiate each cycle. Differences in reactor operational parameters are outlined in Table 1. Initial and cycled media volumes refer to the amount of fresh $2 \times T Y$ media used for initial immobilization (prior to cycle 1) and 2xTY media added following each cycling period, respectively.

\section{Analytical methods}

Total gas production was measured using a frictionless syringe, every $2 \mathrm{~h}$ during the immobilization studies and every $3-10 \mathrm{~h}$ during the scale up study. Hydrogen concentration in the biogas produced was analyzed using a Hewlett Packard GC model 5890 gas chromatograph equipped with a 6A molecular sieve column and a thermal conductivity detector (TCD). The column temperature was maintained at $80{ }^{\circ} \mathrm{C}$, injection temperature at $100{ }^{\circ} \mathrm{C}$ and TCD at $100{ }^{\circ} \mathrm{C}$ with $2.0 \mathrm{ml} / \mathrm{min}$ Argon as a carrier gas. Two-milliliter gas samples were collected from the reactor using a gas-tight Hamilton 2$\mathrm{ml}$ syringe for injection into the GC. Biomass production was also measured every $3-10 \mathrm{~h}$ via optical density measurements. The permanent magnet was first placed against the side of the reactor to separate immobilized biomass from the bulk

Table 1 Operational parameter differences between the three reactor scales

\begin{tabular}{llll}
\hline Reactor & $\begin{array}{l}\text { A-C-NP } \\
\text { Conc. (g/L) }\end{array}$ & $\begin{array}{l}\text { Initial media } \\
\text { volume (L) }\end{array}$ & $\begin{array}{l}\text { Cycled media } \\
\text { volume (L) }\end{array}$ \\
\hline $100 \mathrm{ml}^{\mathrm{a}}$ & 0.25 & 0.040 & 0.030 \\
$100 \mathrm{ml}$ & 0.30 & 0.050 & 0.030 \\
$250 \mathrm{ml}$ & 0.30 & 0.125 & 0.125 \\
$3.6 \mathrm{~L}$ & 0.31 & 1.125 & 1.000 \\
\hline
\end{tabular}

${ }^{\mathrm{a}}$ Immobilization solution. From this bulk solution, 1-ml samples were extracted and measured at $600 \mathrm{~nm}$ with Ocean Optics CHEMUSB4UV-VIS spectrophotometer, (200-850 nm). Substrate consumption during initial immobilization trials was analyzed using the Glucose GO Assay kit from Sigma-Aldrich (Oakville, ON, Canada), following the manufacturer's experimental procedure.

During scale-up trials, glucose and fermentation metabolite concentrations were also analyzed by high-performance liquid chromatography (HPLC). An HP model 1050 HPLC equipped with a Resex ROA Organic Acid $\mathrm{H}+8 \% 150 \times$ $7.8 \mathrm{~mm}$ column was used to measure concentrations of pyruvate, lactate, formate, acetate, butyrate, ethanol, and glucose. The mobile phase used was $0.035 \mathrm{M} \mathrm{H}_{2} \mathrm{SO}_{4}$ at a flow rate of $0.8 \mathrm{ml} / \mathrm{min}$ and run time of $12 \mathrm{~min}$. The column temperature was maintained at $35^{\circ} \mathrm{C}$. UV and refractive index (RI) detectors were used to quantify organic acids and alcohols, respectively. The RI detector was used to measure glucose concentration in each sample. The UV detector was operated at $195 \mathrm{~nm}$ while the RI detector was maintained at $35^{\circ} \mathrm{C}$.

\section{Results}

Nanoparticles coating confirmation

The zeta potential $(\zeta)$ of bare NPs, C-NPs, and A-C-NPs were determined to verify the presence of each coating. Chitosan carries a characteristic positive charge, while alginic acid induces an anionic surface charge. Each value reported in Table 2 represents an average of six zeta potential readings from different batches and errors represent standard deviations between repeated readings. The zeta potentials of coated particles were also measured following autoclaving to determine the effect of sterilization on the coatings. Comparison of the zeta potential before and after autoclaving indicated some coating loss; as indicated by a change of $12-23 \%$ of zetapotential.

Table 2 Zeta potential of bare magnetite nanoparticles, C-NPs and A-C-NPs under varying conditions

\begin{tabular}{llll}
\hline Sample & $\zeta, \mathrm{pH} 3(\mathrm{mV})$ & $\zeta, \mathrm{pH} 7(\mathrm{mV})$ & $\begin{array}{l}\zeta \text {, post-autoclave, } \\
\mathrm{pH} 7(\mathrm{mV})\end{array}$ \\
\hline Bare NPs & $-5.3( \pm 0.9)$ & $-28.2( \pm 1.2)$ & $\mathrm{N} / \mathrm{A}^{\mathrm{d}}$ \\
C-NPs & $47.1( \pm 2.1)$ & $11.4( \pm 1.7)$ & $7.2( \pm 1.2)$ \\
A-C-NPs & N/A & $-45.9( \pm 3.8)$ & $-35.3( \pm 2.0)$ \\
\hline
\end{tabular}

$N P s$ nanoparticles, $C-N P s$ chitosan nanoparticles, $A-C-N P s$ alginatechitosan-nanoparticles

${ }^{a} \mathrm{~N} / \mathrm{A}$ represents unachievable conditions due to the polyelectrolyte properties (A-C-NPs, $\mathrm{pH} 3)$ or irrelevant conditions to immobilization (autoclaved bare nanoparticles, $\mathrm{pH}$ 7) 
TEM images were also analyzed to visually confirm the presence of the layers and ensure that coated particles remained below $100 \mathrm{~nm}$ in diameter. Figure 1 displays images confirming that the nanoparticles size remained below $100 \mathrm{~nm}$ and the white arrows in Fig. 1b, c indicate the presence of chitosan and chitosan-alginic acid layers (lighter color surrounding the particles), respectively. Therefore, the layer-bylayer method successfully functionalized the magnetite NPs, preparing them for bacterial immobilization.

\section{Bacterial immobilization confirmation}

Initial trials in the 100-ml reactor indicated increased gas production and a shorter lag growth phase with A-C-NPs compared to controls (no nanoparticles) but only for the second immobilization cycle, as depicted in Fig. 2a (gas production) and Fig. 2b (growth). There were no large differences in hydrogen production between the A-C-NP samples and control during the first and third cycles. However, during the second cycle, A-C-NP samples produced a 3-fold increase in hydrogen compare to the control. The differences observed in the various cycles were not explained but hypothesis are provided in the discussion section. The results obtained, particularly the shorter lag growth phase, indicated that more biomass was retained within the $\mathrm{A}-\mathrm{C}-\mathrm{NP}$ reactors than in the controls. To confirm this retention was due to the attachment of NPs to the bacterial cell wall, samples incubated with NPs during the preculture step were imaged. Results shown in Fig. 3a confirm that immobilization occurred in the first cycle. A second sample, consisting of bacteria that had been cycled once, is shown in Fig. $3 b$ and confirms that the cycling process did not reverse the immobilization procedure or strip NPs from the cell wall. Although Fig. 3a suggests a possible agglomeration of NPs on the surface of the bacteria, these images confirm that the immobilization procedure was successful in attaching $\mathrm{A}-\mathrm{C}-\mathrm{NPs}$ to bacterial cell walls.

\section{Fermentation results}

Over the course of three fermentation cycles, the 100-ml reactors containing NPs produced $85.1 \mathrm{ml}$ of hydrogen as depicted in Fig. 2a. This equates to a volumetric production of $14.2( \pm 1.5) \mathrm{ml}-\mathrm{H}_{2} / \mathrm{L} / \mathrm{h}$ and molar production of $0.6( \pm 0.1)$ $\mathrm{mmol} / \mathrm{L} / \mathrm{h}$. Liquid samples collected from the reactors containing NPs were analyzed using the HPLC method described in the analytical methods section. The only liquid metabolites produced in measureable quantities were ethanol, acetate, and formate, as shown in Fig. 4. The patterns of production were similar from one cycle to another, with glucose conversion in the 16-32\% range, ethanol and acetate produced in comparable amounts and a lower production of formate (about three times less than the other metabolites).

The resulting total hydrogen, ethanol, acetate, and formate production across all cycles of each reactor are presented in Fig. 5 to facilitate comparison of results at the different scales tested. The 250-ml reactors experienced a significant loss of immobilized biomass during the cycling process, which resulted in large errors in hydrogen production and biomass growth during cycle two. This loss was due to limited ability to retain the NPs using the magnets available at that time. Due to such a large loss of A-C-NPs, the 250-ml reactor was only cycled twice (as opposed to three times). Bigger magnets were used for the 3.6-L reactor and it was possible to achieve three cycles in this larger reactor. The $250-\mathrm{ml}$ reactor resulted in a volumetric hydrogen production of 77.6 ( \pm 33.4$) \mathrm{ml} / \mathrm{L} / \mathrm{h}$ (comparable to the value of $85.1 \mathrm{ml} / \mathrm{L} / \mathrm{h}$ obtained in the immobilization study) and molar production of $3.2( \pm 1.4) \mathrm{mmol} / \mathrm{L} / \mathrm{h}$ (see Fig. 5). The 3.6-L dataset are preliminary in nature (no replicate) but results indicated a volumetric hydrogen production of $37.6 \mathrm{ml} / \mathrm{L} /$ $\mathrm{h}$ and molar production of $1.6 \mathrm{mmol} / \mathrm{L} / \mathrm{h}$, values lying between the other two scales tested. The relative production profiles of all metabolites were similar across all scales (ethanol and acetate representing the primary and secondary metabolites respectively), however, formate was not detected at the largest scale. The 3.6-L reactor dataset suggest a shift in metabolic processes at this larger scale as no formate was produced in measureable quantities.

\section{Process efficiencies}

Substrate conversion efficiency (SCE), energy conversion efficiency (ECE) and specific hydrogen productivity (SHP) were determined to evaluate the overall performance of the

Fig. 1 TEM images of bare magnetite (a), C-NPs (b) and A$\mathrm{C}-\mathrm{NPs}(\mathbf{c})$. The presence of coating can be seen as a light color layer surrounding the particles, as indicated with white arrows
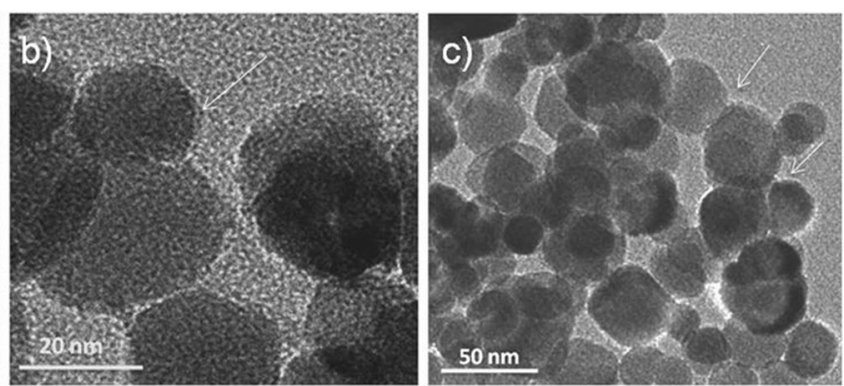

$50 \mathrm{~nm}$

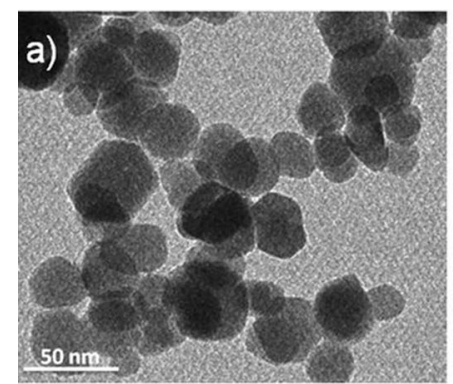


Fig. 2 Cumulative hydrogen production (a) and biomass profile (b) observed in 100-mL reactors containing bacteria immobilized on A-C-NPs $(A-C-$ $N P)$ or suspended bacteria (Control). Error bars represent the maximum and minimum values of the experimental runs. Suspended biomass growth was measured by optical density at $600 \mathrm{~nm}$
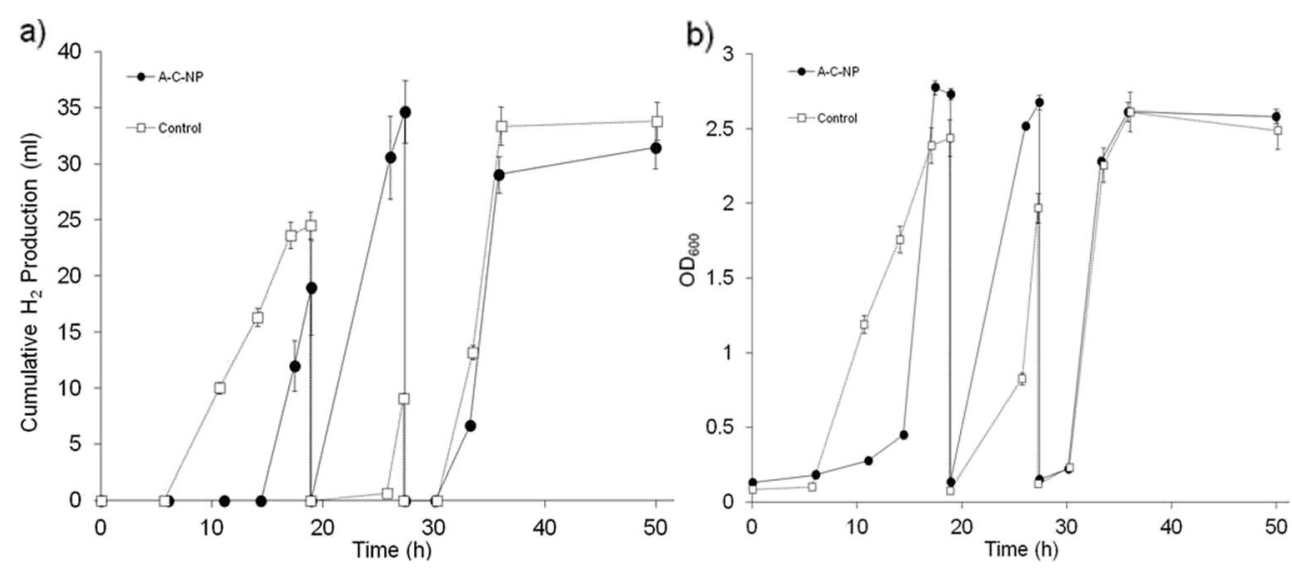

hydrogen production process. SCE was calculated based on the complete theoretical conversion of glucose to hydrogen, yielding 4 mol of hydrogen for every $1 \mathrm{~mol}$ of glucose consumed (Levin et al. 2004). Therefore, the SCE was calculated according to Eq. 1:

$\mathrm{SCE}=\frac{\mathrm{mol}_{\mathrm{H}_{2} \text { produced }}}{\mathrm{mol}_{\text {glucose added }}} \cdot \frac{1 \mathrm{~mol} \text { glucose }}{4 \mathrm{molH}_{2}} \cdot 100 \%$

The amount of hydrogen produced was converted from volume to moles assuming hydrogen acted as an ideal gas. The pressure was assumed to be atmospheric (1 atm) and at room temperature in the lab $\left(21^{\circ} \mathrm{C}\right)$. The ECE was calculated comparing the total specific energy of glucose added to the system to the total specific energy of hydrogen produced. The specific energy (or energy density) of hydrogen is $142 \mathrm{~kJ} / \mathrm{g}$ (Ghosh and Hallenbeck 2014), while that of glucose is $16 \mathrm{~kJ} / \mathrm{g}$ (Kraisid 2003). Therefore, the ECE is given by Eq. 2:

$\mathrm{ECE}=\frac{m_{\mathrm{H}_{2}} \cdot E_{\mathrm{H}_{2}}}{m_{\text {glucose }} \cdot E_{\text {glucose }}} \cdot 100 \%$ $m_{x}$ represents the mass of hydrogen produced or glucose added in grams, while $E_{x}$ represents the specific energy of the corresponding component.

The SHP based on biomass growth was determined from the ratio of hydrogen produced to maximum biomass reading according to Eq. 3:

$\mathrm{SHP}=\frac{\mathrm{mmol}_{\mathrm{H}_{2} \text { produced }}}{\mathrm{OD} 600}$

Figure 6 depicts the efficiencies and specific productivity calculated for each reactor size. This data indicates an initial increase in efficiency when scaling up to the $250-\mathrm{ml}$ reactors, followed by a large decrease when scaled up further to the 3.6-L reactor. The exception to this trend was the specific hydrogen productivity normalized against biomass optical density reading, which significantly increased at the highest reactor scale. Large changes in optical density measurements were not expected from scale to scale; however, the amount of hydrogen produced was expected to vary directly with reactor size, which might explain this result.
Fig. 3 TEM images of precultured bacteria (a) and cycled bacteria (b). Black arrows represent visual confirmation of NPs attached to the bacterial cell wall

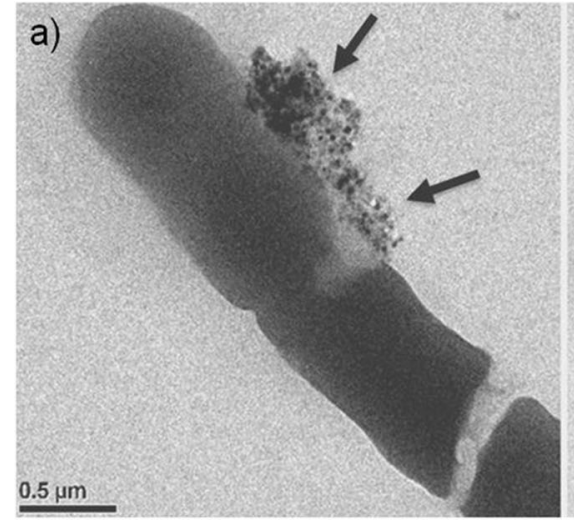

b)

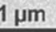




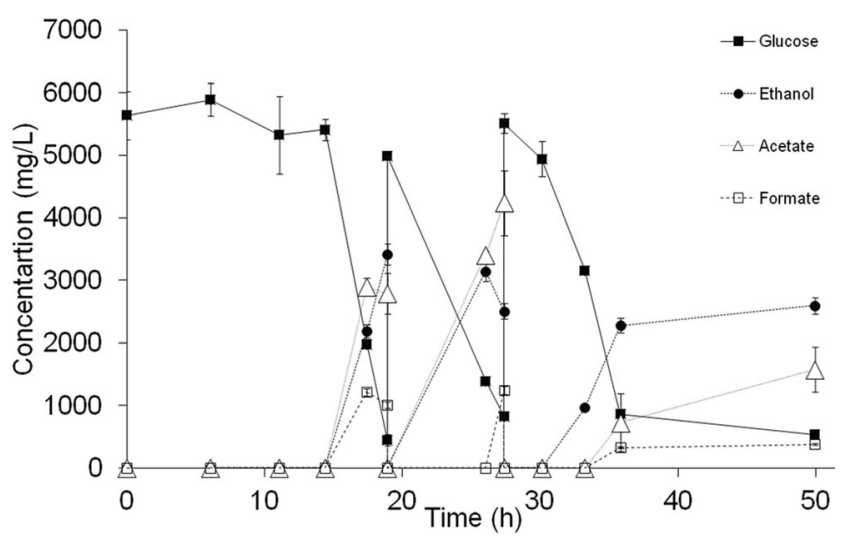

Fig. 4 Profiles of the concentration of glucose and three metabolites over 3 cycles of production in $100-\mathrm{mL}$ reactors containing bacteria immobilized on A-C-NPs. Metabolites include ethanol, acetate, and formate. Error bars represent the maximum and minimum values of the experimental runs

\section{Discussion}

Cycling and scale up of the reactors

Based on the results presented above, the addition of $\mathrm{A}-\mathrm{C}-$ NPs can provide greater biomass retention between cycles and shorten each lag phase (Fig. 2, data not shown for the 250-ml and 3.6-L reactors). The greater hydrogen production obtained in the second fermentation cycle of the $100-\mathrm{ml}$ reactors containing A-C-NP (3-fold increase) was likely due to an acclimation period during the first cycle. An increase in total hydrogen production was also observed in the larger-scale reactors containing $\mathrm{A}-\mathrm{C}-\mathrm{NP}$ when compared to their respective controls operated with suspended cells (23\% increase for the $250-\mathrm{mL}$ reactor and $98 \%$ increase in the $3.6-\mathrm{L}$ reactor, data not shown). However, acclimation over the cycle was not significant for the $250-\mathrm{mL}$ and $3.6-\mathrm{L}$ reactors. The variability observed between the cycles performed in the $100-\mathrm{mL}$ reactor

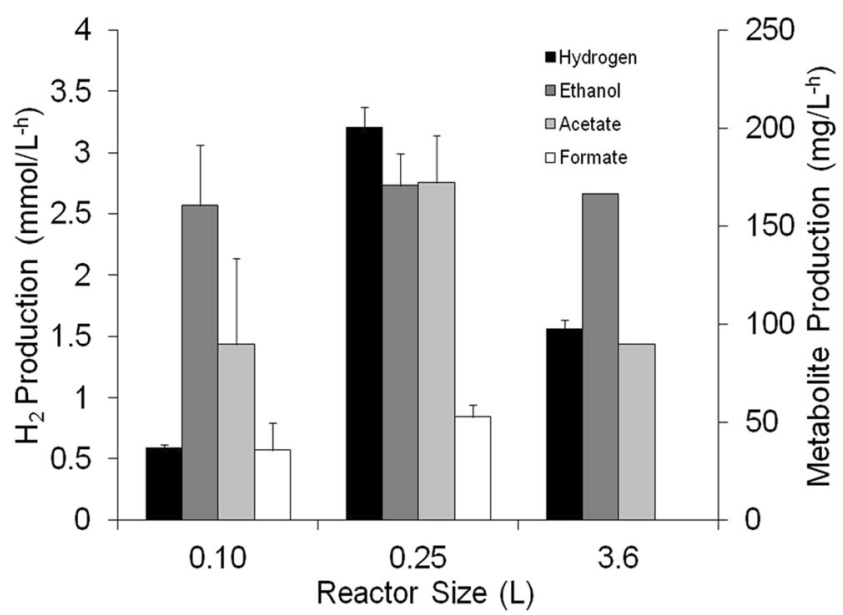

Fig. 5 Total hydrogen and metabolite production for the three reactor scales using bacteria immobilized on A-C-NPs. Error bars represent the maximum and minimum values of the experimental runs

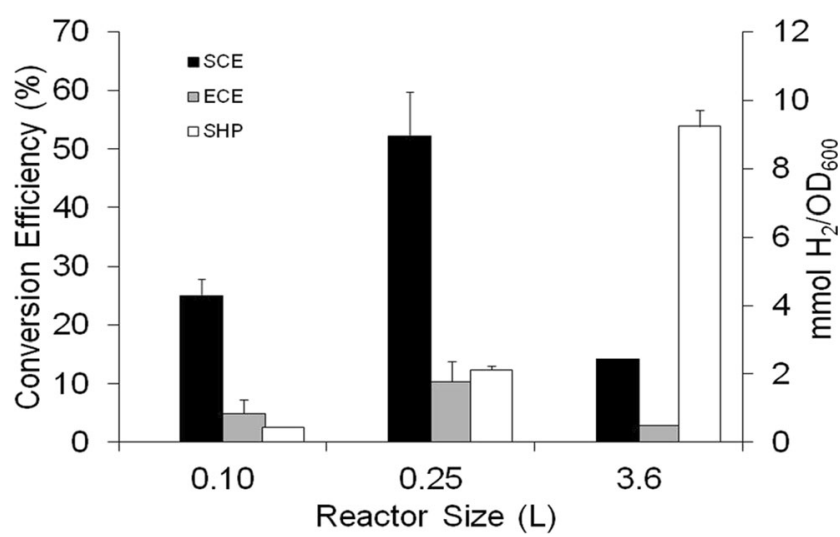

Fig. 6 Substrate conversion efficiency $(S C E)$, energy conversion efficiency $(E C E)$ and specific hydrogen productivity $(S H P)$ for the three reactor scales. Error bars represent the maximum and minimum values of the experimental runs

but not in the larger scale reactors might be explained by the small total initial population inoculated in the $100-\mathrm{mL}$ reactors.

The overall SCE increased during scale-up to $250 \mathrm{ml}$ but decreased significantly when scaled up to $3.6 \mathrm{~L}$. This may be due to changes in metabolic pathways as the large decrease in SCE was not accompanied by a corresponding increase in the ethanol detected. In evaluating the specific trends in metabolite production (Fig. 5), ethanol concentrations remained relatively constant between scales while acetate and formate concentrations exhibited a pattern following the changes in SCE and were at lower concentrations in the 3.6-L reactor. One hypothesis is that the differences in SCE are associated with the formation of numerous other metabolites that were produced in quantities below the limit of quantification of our method and instrument. Such potential metabolites include lactate, propionate, acetaldehyde, and butyrate. The formation of butyrate would have a compounding effect, as its production would also result in higher $\mathrm{CO}_{2}$ production (Levin et al. 2004). Looking at the hydrogen concentration measured in the reactor head spaces, which ranged from $27 \%$ to $45 \%$ in the $100-\mathrm{ml}$ reactors, $27-74 \%$ in the $250-\mathrm{ml}$ reactors, and 20 $37 \%$ in the 3.6-L reactor, no clear trend was observed between the various scales suggesting that butyrate was not produced in greater quantities. This is likely due to the primary production of ethanol competing with the butyric acid pathway (Lee et al. 2008). The production of acetate during fermentation is an unavoidable by-product of hydrogen production and it is only produced under the regeneration of ATP (cellular energy), which can be used to further produce biomass (and thus indirectly produce hydrogen) as shown in Fig. S1. Therefore the presence of acetate is not intolerable. Ethanol, however, is a by-product of a metabolic pathway that not only terminates without additional hydrogen production, but produces metabolites which compete with hydrogen producing reactions. This pathway utilizes $1 \mathrm{~mol}$ of $\mathrm{NADH}$ to 
Table 3 Hydrogen yield and molar productivity comparison under different reactor scales and operations

\begin{tabular}{|c|c|c|c|c|c|c|}
\hline \multirow[t]{2}{*}{ Responses } & \multicolumn{3}{|c|}{ Volume of the reactor } & \multicolumn{3}{|c|}{$\begin{array}{l}\text { Rittmann Herwig index } \\
\text { (Rittmann and Herwig } \\
\text { 2012) }\end{array}$} \\
\hline & $100 \mathrm{ml}$ & $250 \mathrm{ml}$ & $3.6 \mathrm{~L}$ & Min. & Med. & Max. \\
\hline $\mathrm{Y}_{(\mathrm{H} 2 / \mathrm{S})}{ }^{\mathrm{a}}$ & $1.0( \pm 0.1)$ & $2.1( \pm 0.7)$ & 0.6 & 0.51 & 0.51 & 2.8 \\
\hline $\mathrm{P}_{\mathrm{H} 2}{ }^{\mathrm{b}}$ & $0.6( \pm 0.1)$ & $3.2( \pm 1.4)$ & 1.6 & 2.09 & 17.9 & 27.2 \\
\hline
\end{tabular}

${ }^{\mathrm{a}}$ Molar hydrogen yield (in mole per mole of glucose)

${ }^{\mathrm{b}}$ Molar hydrogen productivity (in millimole per liter per hour)

produce acetaldehyde and $1 \mathrm{~mol}$ of $\mathrm{NAD}^{+}$. Acetaldehyde is then further metabolized using $1 \mathrm{~mol}$ of NADH to produce ethanol and $1 \mathrm{~mol}$ of $\mathrm{NAD}^{+}$. Therefore, every time ethanol is produced, at least 2 mol of $\mathrm{NAD}^{+}$are released. $\mathrm{NAD}^{+}$can then be recycled back to NADH in a reaction competing with hydrogen production (Lee et al. 2008). It is thus clear that the high presence of ethanol indicates the organisms are not efficiently producing hydrogen. The fact ethanol is the primary metabolite produced over all three reactor scales also indicates there is significant room for improving process efficiency on a cellular level.

ECE remained relatively unchanged between the 100-ml and 250-ml reactors; however it decreased when scaling up to the 3.6-L reactor. Again, this trend was likely due to the changes in metabolic pathways. The SHP steadily increased with each scale-up as expected. The maximum optical density between different-sized reactors did not change significantly, however, the total amount of hydrogen produced changed in proportion to reactor size. Perhaps the most intriguing difference was the changes in molar hydrogen yield between scales. Hydrogen yield increased from the 100-ml reactors to the 250-ml reactors, but then decreased when scaling up was done to the 3.6-L reactor. This indicates unwanted side reactions or metabolic pathways taking place within the $3.6-\mathrm{L}$ reactor. This discrepancy may be due to large changes in environmental conditions such as type of agitation (stirred incubator vs. impeller), $\mathrm{pH}$ (decreasing vs. constant), antifoaming agent (notpresent vs. present), oxygen partial pressure $\left(\mathrm{pO}_{2}\right)$ control (small volume vs. large volume) (Bartacek et al. 2007), and overall changes in process techniques as described in the scale-up of biohydrogen production section.

Table 4 Overview of hydrogen yield obtained using different immobilization approaches and free-cell systems

\begin{tabular}{|c|c|c|c|c|}
\hline Microorganism & Parameters & Immobilizing material & $Y_{(\mathrm{H} 2 / \mathrm{s})}(\mathrm{mol} / \mathrm{mol}$ glucose $)$ & Reference \\
\hline $\begin{array}{l}\text { C. beijerinckii } \\
\text { NCIMB } 8052\end{array}$ & $\begin{array}{l}250-\mathrm{ml} \text { batch } \\
37^{\circ} \mathrm{C}, \mathrm{pH} 7.0,5 \mathrm{~g} / \mathrm{L} \text { glucose }\end{array}$ & Alginate-chitosan-NPs & 2.1 & Present study \\
\hline Clostridium sp. LS2 & $\begin{array}{l}5 \text {-L continuous UASB } \\
37^{\circ} \mathrm{C}, \mathrm{pH} 5.5 \\
\text { HRT } 12 \mathrm{~h} \text { with } 5 \mathrm{~g} \mathrm{COD} / \mathrm{L} / \mathrm{h}\end{array}$ & Polyethylene glycol gel & $\begin{array}{l}0.35 \mathrm{~L} \mathrm{H} 2 / \mathrm{g} \mathrm{COD} \\
\text { removed } \\
(\mathrm{PEG})\end{array}$ & Singh et al. (2013) \\
\hline Clostridium sp. T2 & $\begin{array}{l}\text { 1-L CSTR } \\
37^{\circ} \mathrm{C}, \mathrm{pH} 7.0,10 \mathrm{~g} / \mathrm{L} \text { xylose }\end{array}$ & $\begin{array}{l}\text { Sodium alginate/mycelia } \\
\text { pellets }\end{array}$ & Not available & Zhao et al. (2012) \\
\hline $\begin{array}{l}\text { C. beijerinckii } \\
\text { RZF-1108 }\end{array}$ & $\begin{array}{l}100-\mathrm{ml} \text { batch } \\
35^{\circ} \mathrm{C} \text {, pH } 7.0 \text {, HRT } 8-12 \mathrm{~h}, 9 \mathrm{~g} / \mathrm{L} \text { glucose }\end{array}$ & Free suspension & 1.97 & Zhao et al. (2011) \\
\hline $\begin{array}{l}\text { C. tyrobutyricum } \\
\text { ATCC } 25755\end{array}$ & $\begin{array}{l}\text { Fed batch } \\
\text { 2-L working volume } \\
37^{\circ} \mathrm{C}, \mathrm{pH} 5.7 \text {, HRT } 8 \text { h, } 30 \text { g glucose/L }\end{array}$ & Polyurethane matrix & 2.0 & Mitchell et al. (2009) \\
\hline $\begin{array}{l}\text { C. tyrobutyricum } \\
\text { JM1 }\end{array}$ & $\begin{array}{l}\text { Continous } \\
\text { Fixed bed reactor } \\
2.5-\mathrm{L} \text { working volume } \\
37^{\circ} \mathrm{C}, \mathrm{pH} 6.7 \text {, HRT } 2 \mathrm{~h}, 5 \mathrm{~g} \text { glucose } / \mathrm{L}\end{array}$ & polyurethane foam & $223 \mathrm{ml} / \mathrm{g}$ hexose & Jo et al. (2008) \\
\hline $\begin{array}{l}\text { C. beijerinckii } \\
\text { Fanp3 }\end{array}$ & $\begin{array}{l}140-\mathrm{ml} \text { batch } \\
36^{\circ} \mathrm{C}, \mathrm{pH} 6.5,200 \mathrm{~g} / \mathrm{L} \text { glucose }\end{array}$ & Free suspension & 1.86 & Pan et al. (2008) \\
\hline $\begin{array}{l}\text { Clostridium sp. } \\
\text { AK15 }\end{array}$ & $\begin{array}{l}300-\mathrm{ml} \text { batch } \\
60{ }^{\circ} \mathrm{C}, \mathrm{pH} 6.0\end{array}$ & Free suspension & 0.8 & Koskinen et al. (2008) \\
\hline $\begin{array}{l}\text { Clostridium sp. } \\
\text { W1 }\end{array}$ & $\begin{array}{l}800-\mathrm{ml} \text { batch } \\
35^{\circ} \mathrm{C} \text {, potato wastewater }\end{array}$ & Free suspension & 0.51 & Wang et al. (2007) \\
\hline Clostridium sp. & $\begin{array}{l}\text { 1-L batch } \\
36{ }^{\circ} \mathrm{C}, \mathrm{pH} 6.0,10 \mathrm{~g} / \mathrm{L} \text { glucose }\end{array}$ & Free suspension & 1.8 & Taguchi et al. (1994) \\
\hline C. butyricum & $\begin{array}{l}\text { Batch (shrenk flask) } \\
37^{\circ} \mathrm{C}, \mathrm{pH} 7.0,55 \mu \text { moles glucose }\end{array}$ & Acetylcellulose filter & 2.0 & Karube et al. (1982) \\
\hline Anaerobic sludge & $\begin{array}{l}\text { 2-L fluidized bed } \\
40{ }^{\circ} \mathrm{C}, 6 \mathrm{~h} \text { HRT } \\
20 \mathrm{gCOD} / \mathrm{L} \text { sucrose }\end{array}$ & $\begin{array}{l}\text { Ethylene-vinyl } \\
\text { acetate copolymer }\end{array}$ & 4.26 & Lin et al. (2009) \\
\hline Anaerobic sludge & $\begin{array}{l}\text { 8-L draft tube } \\
\text { Fluidized bed } \\
40{ }^{\circ} \mathrm{C} \text {, HRT } 8.9 \text { h, } 40 \text { gCOD/L sucrose }\end{array}$ & Silicone gel & 4.98 & Lin et al. (2006) \\
\hline
\end{tabular}


Overall, the proposed immobilizing and cycling procedure was successful when applied across all reactor sizes but variations were observed from one cycle to another. There is still room for improvement in cycling conditions and techniques, which might further enhance the effect of A-C-NPs on the sustainable production of hydrogen.

\section{Hydrogen yield obtained}

In order to facilitate comparison of the hydrogen production obtained to previously published data, Table 3 presents the equivalent molar yield of hydrogen $\left(Y_{\mathrm{H} 2 / \mathrm{S}}\right.$; in mole of $\mathrm{H}_{2}$ per mole of glucose) and molar hydrogen productivity (in millimole per liter per hour) obtained at each scale. The hydrogen yields $\left(Y_{\mathrm{H} 2 / \mathrm{S}}\right)$ obtained in the present study lie within the range of data reported in a review of dark fermentation published by Rittmann and Herwig (2012). However, the hydrogen productivity obtained for all three reactor sizes were relatively low ( 0.6 to $3.2 \mathrm{mmol} / \mathrm{L} / \mathrm{h}$ ) when compared to the range reported in the same review ( 2.09 to $27.1 \mathrm{mmol} / \mathrm{L} / \mathrm{h}$ ).

Considering that the major objective of this study was to improve hydrogen production using $C$. beijerinckii immobilized on chitosan-alginic acid polyelectrolyte functionalized magnetite nanoparticles, results obtained are compared to molar hydrogen yields (in moles of hydrogen per mole of glucose) reported in literature. Table 4 summarizes the key parameters and results of the most relevant studies. All the previous studies performed using immobilized Clostridium butyricum, either using PEG (Singh et al. 2013), alginate bead (Zhao et al. 2012), polyurethane foam (Jo et al. 2008), polyurethane-activated carbon matrix (Mitchell et al. 2009), or acetyl cellulose fiber (Karube et al. 1982) demonstrated similar or increased molar hydrogen yield when compared to free-cell systems. There are also indications in literature that Clostridium sp. CFPA-20 is thermodynamically favored for immobilization (Nomura et al. 2014). The molar hydrogen yield obtained in this study is in the range of the values reported in literature for immobilized cells. However, for all the studies reported, major issues still remain about the reusability, stability, and regeneration of immobilizing materials that had been previuosly used. The approach used here would facilitate such recovery of the immobilized cells.

Based on the results obtained in this study, magnetite nanoparticles were successfully coated with chitosan and alginic acid layers and for the first time, attachment of $C$. beijerinckii cultures to this immobilization material was confirmed. This immobilization technique enabled the retention of biomass within bioreactors of varying sizes and use in successive batch fermentations for hydrogen production. This process has the advantages of reducing downtime between batches and increasing the volumetric production of hydrogen over a given time period. Although efficiency and processing issues presented themselves, it was shown that the use of a strong enough magnetic field can retain the immobilized biomass within the reactor, leading to greater amounts of hydrogen being produced than in a control reactor operated with a free suspension over the same time period. However, the low substrate and energy conversion efficiencies compared to previously published data indicate that there is room for improvement. Considering the decrease in some process efficiencies during scale up from $250-\mathrm{ml}$ to $3.6-\mathrm{L}$ reactors, operating factors such as agitation, $\mathrm{pH}$, antifoaming, and $\mathrm{pO}_{2}$ must be optimized in order to maximize hydrogen yields. Optimization of media components or reactor conditions could also be considered in order to promote greater hydrogen production from a metabolic standpoint while suppressing ethanol formation. A promising avenue for improvement of the hydrogen production is based on the metabolic carbon flow and reduced equivalent regeneration and utilization (e.g., NADH, NAD[P]H). NADH regeneration and utilization is predominantly dominated by ethanol, lactate and butanol metabolic networks, which are indirectly competing with hydrogen generation involving PFOR and NFOR pathways, as shown in Fig. S1. Previous studies showed that regeneration of reduced equivalents by immobilized C. butyricum is feasible but that the bottleneck is the hydrogen partial pressure (Matsunaga et al. 1985). In the current study, ethanol and acetate were the most predominant end metabolites and ethanol was produced over all three reactor scales, indicating space for improving the hydrogen yield by knocking out those competing metabolic pathways. The immobilization on chitosan-alginic acid polyelectrolyte functionalized magnetite nanoparticles of metabolically engineered $C$. beijerinckii may be a promising future option for sustainable production of biohydrogen.

Acknowledgments We would like to thank Prof. Patrick C. Hallenbeck for his technical advice throughout the project. Special thanks to Mr. Ranjan Roy for his help with analytical equipment and to Dr. David Liu for his help with TEM imaging. Funding for this research was provided by FRQNT - Project de recherche en équipe. T. Seelert and D. Ghosh were supported by a Eugenie Ulmer Lamothe and FQRNT-PBEEE Scholarships, respectively.

Conflict of interest The authors do not have potential conflict of interest to disclose.

Ethical statement The authors confirm that principles of ethical and professional conduct have been followed in this research and in the preparation of this manuscript.

\section{References}

Bartacek J, Zabranska J, Lens PNL (2007) Developments and constraints in fermentative hydrogen production. Biofuels Bioprod Biorefin 1(3):201-214. doi:10.1002/bbb.17

Brentner LB, Peccia J, Zimmerman JB (2010) Challenges in developing biohydrogen as a sustainable energy source: implications for a 
research agenda. Environ Sci Technol 44(7):2243-2254. doi:10. 1021/es9030613

Conti J, Holtberg P (2011) International Energy Outlook U.S.E.I. Administration, Washington, DC.DOE/EIA-0484(2011). http:// large.stanford.edu/courses/2012/ph241/miller1/docs/0484-2011. pdf. Accessed September 2011

Cranston GR, Hammond GP (2010) North and south: regional footprints on the transition pathway towards a low carbon, global economy. Appl Energ 87(9):2945-2951. doi:10.1016/j.apenergy.2009.08.015

Cullen JM, Allwood JM (2010) The efficient use of energy: tracing the global flow of energy from fuel to service. Energ Policy 38:75-81. doi:10.1016/j.enpol.2009.08.054

Decher G (1997) Fuzzy nanoassemblies: toward layered polymeric multicomposites. Science 277(5330):1232-1237. doi:10.1126/ science. 277.5330 .1232

Ghosh D, Hallenbeck PC (2014) Metabolic engineering: key for improving biological hydrogen production. In: Lu X (ed) Biofuels from microbes to molecules, 1st edn. Horizon Scientific Press, United Kingdom, pp 1-46

Ghosh D, Pramanik P (2010) Low molecular weight biodegradable polymer based nanoparticles as potential delivery systems for therapeutics: the way forward? Int J Pharm Sci Drug Res 2(1):31-34

Ghosh D, Pramanik A, Sikdar N, Ghosh SK, Pramanik P (2010) Amelioration studies on optimization of low molecular weight chitosan nanoparticle preparation, characterization with potassium per sulphate and silver nitrate combined action with aid of drug delivery to tetracycline resistant bacteria. Int J Pharm Sci Drug Res 2(4):247253

Ghosh D, Pramanik A, Sikdar N, Pramanik P (2011) Synthesis of low molecular weight alginic acid nanoparticles through persulfate treatment as effective drug delivery system to manage drug resistant bacteria. Biotechnol Bioprocess Eng 16(2):383-392. doi:10.1007/ s12257-010-0099-7

Hallenbeck PC, Ghosh D (2009) Fermentative hydrogen production: the way forward? Trends Biotechnol 27:287-297. doi:10.1016/j.tibtech. 2009.02 .004

Jo JH, Lee DS, Park D, Park JM (2008) Biological hydrogen production by immobilized cells of Clostridium tyrobutyricum JM1 isolated from a food waste treatment process. Bioresour Technol 99(14): 6666-6672. doi:10.1016/j.biortech.2007.11.067

Karube I, Urano N, Matsunaga T, Suzuki S (1982) Hydrogen production from glucose by immobilized growing cells of Clostridium butyricum. Eur J Appl Microbiol Biotechnol 16:5-9. doi:10.1007/ BF01008235

Koskinen PEP, Beck SR, Örlygsson J, Puhakka JA (2008) Ethanol and hydrogen production by two thermophilic, anaerobic bacteria isolated from Icelandic geothermal areas. Biotechnol Bioeng 101:679690. doi:10.1002/bit.21942

Kothari R, Tyagi VV, Pathak A (2010) Waste-to-energy: a way from renewable energy sources to sustainable development. Renew Sust Energ Rev 14(9):3164-3170. doi:10.1016/j.rser.2010.05.005

Kraisid, T (2003) Rome: Food and Agriculture Organization of the United Nations, Rome, (2003). http://www.fao.org/uploads/media/ FAO_2003_Food_Energy_02.pdf. Accessed December 2003

Lee H-S, Salerno MB, Rittmann BE (2008) Thermodynamic evaluation on $\mathrm{H}_{2}$ production in glucose fermentation. Environ Sci Technol 42(7):2401-2407. doi:10.1021/es702610v

Levin DB, Pitt L, Love M (2004) Biohydrogen production: prospects and limitations to practical application. Int J Hydrog Energy 29(2):173185. doi:10.1016/S0360-3199(03)00094-6

Li YG, Gao HS, Li WL, Xing JM, Liu HZ (2009) In situ magnetic separation and immobilization of dibenzothiophene-desulfurizing bacteria. Bioresour Technol 100(21):5092-5096. doi:10.1016/j. biortech.2009.05.064

Lin CN, Wu SY, Chang JS (2006) Fermentative hydrogen production with a draft tube fluidized bed reactor containing silicone-gelimmobilized anaerobic sludge. Int J Hydrog Energy 31(15):2200 2210. doi:10.1016/j.ijhydene.2006.05.012

Lin CN, Wu SY, Chang JS, Chang JS (2009) Biohydrogen production in a three-phase fluidized bed bioreactor using sewage sludge immobilized by ethylene-vinyl acetate copolymer. Bioresour Technol 100(13):3298-3301. doi:10.1016/j.biortech.2009.02.027

Masereel B, Dinguizli M, Bouzin C, Moniotte N, Feron O, Gallez B, Borght TV, Michiels C, Lucas S (2011) Antibody immobilization on gold nanoparticles coated layer-by-layer with polyelectrolytes. J Nanopart Res 13(4):1573-1580. doi:10.1007/s11051-010-9908-3

Matsunaga T, Matsunaga N, Nishimura S (1985) Regeneration of $\mathrm{NAD}(\mathrm{P}) \mathrm{H}$ by immobilized whole cells of Clostridium butyricum under hydrogen high pressure. Biotechnol Bioeng 27(9):12771281. doi:10.1002/bit.260270902

Mitchell RJ, Kim J-S, Jeon B-S, Sang B-I (2009) Continuous hydrogen and butyric acid fermentation by immobilized Clostridium tyrobutyricum ATCC 25755: effects of the glucose concentration and hydraulic retention time. Bioresour Technol 100:5352-5355. doi:10.1016/j.biortech.2009.05.046

Nomura T, Naimen A, Toyoda S, Kuriyama Y, Tokumoto H, Konishi Y (2014) Isolation and characterization of a novel hydrogen-producing strain Clostridium sp. suitable for immobilization. Int J Hydrog Energ 39:1280-1287. doi:10.1016/j.ijhydene.2013.10.166

Pan C-M, Fan Y-T, Zhao P, Hou H-W (2008) Fermentative hydrogen production by the newly isolated Clostridium beijerinckii Fanp3. Int J Hydrogen Energy 33(20):5383-5391. doi:10.1016/j.ijhydene. 2008.05.037

Pielke R, Wigley T, Green C (2008) Dangerous assumptions. Nature 452(7187):531-532. doi:10.1038/452531a

Pillai CKS, Paul W, Sharma C (2009) Chitin and chitosan polymers: chemistry, solubility and fiber formation. Prog Polym Sci 34(7): 641-678. doi:10.1016/j.progpolymsci.2009.04.001

Rittmann S, Herwig C (2012) A comprehensive and quantitative review of dark fermentative biohydrogen production. Microb Cell Fact 11: 115. doi:10.1186/1475-2859-11-115

Singh L, Siddiqui MF, Ahmad A, Rahima MHA, Sakinah, Wahid ZA (2013) Application of polyethylene glycol immobilized Clostridium $\mathrm{sp}$. LS2 for continuous hydrogen production from palm oil mill effluent in up flow anaerobic sludge blanket reactor. Biochem Eng J 70:158-165. doi:10.1016/j.bej.2012.10.010

Taguchi F, Mizukami N, Hasegawa K, Saito-Taki T (1994) Microbial conversion of arabinose and xylose to hydrogen by a newly isolated Clostridium sp. No. 2. Can J Microbiol 40(3):228-233. doi:10.1139/ $\mathrm{m} 94-037$

Wang X, Hoefel D, Saint CP, Monis PT, Jin B (2007) The isolation and microbial community analysis of hydrogen producing bacteria from activated sludge. J Appl Microbiol 103:1415-1423. doi:10.1111/j. 1365-2672.2007.03370.x

Ye S, Wang C, Liu X, Tong Z (2005) Multilayer nanocapsules of polysaccharide chitosan and alginate through layer-by-layer assembly directly on PS nanoparticles for release. J Biomater Sci Polym Ed 16(7):909-923. doi:10.1163/1568562054255691

Zhao X, Xing D, Fu N, Liu B, Ren N (2011) Hydrogen production by the newly isolated Clostridium beijerinckii RZF-1108. Bioresour Technol 102(18):8432-8436. doi:10.1016/j.biortech.2011.02.086

Zhao L, Cao G-L, Wang A-J, Guo W-Q, Liu B-F, Rena H-Y, Rena N-Q, Ma F (2012) Enhanced bio-hydrogen production by immobilized Clostridium sp. T2 on a new biological carrier. Int J Hydrog Energ 37:162-166. doi:10.1016/j.ijhydene.2011.09.103 